\title{
SOUTH AFRICA AND THE SEARCH FOR STRATEGIC EFFECT IN THE CENTRAL AFRICAN REPUBLIC
}

\section{Francois Vrë̈ and Abel Esterhuyse Stellenbosch University}

\begin{abstract}
This article provides a critical assessment from a strategic perspective of the South African military involvement in the Central African Republic that culminated in the Battle of Bangui. The strategic assessment was aimed at an understanding of the South African armed forces and their government's strategic approach and logic (i.e. strategic ways) through a consideration of, firstly, their strategic objectives and end states and, secondly, a critical reflection on the military means that were available and employed in the Central African Republic. The authors question the logic of South African political and military objectives through an emphasis on the absence of South African interests in the Central African Republic, the failure of the executive to inform parliament, the dubious and blurred intentions of the African National Congress government and the absence of a clear political-military nexus for the operation. The lack of sufficient military capabilities for the deployment was assessed through a consideration of overstretch, obsolescence, neglect and mismanagement of military resources. The article concludes that not only did the government set the military up for failure; it also succeeded in creating the perfect conditions for a strategic fiasco.
\end{abstract}

\section{Introduction}

In Africa, organised violence is still responsible for the death and displacement of many on the continent. A youthful population, poverty, weak

Scientia Militaria, South African Journal of Military Studies, Vol 44, No. 2, 2016, pp. 1-27. doi: $10.5787 / 44-2-1174$ governance, a lack of infrastructure and a shattered education system are amongst the factors that still breed violent - mostly intrastate - conflict. $^{1}$ In addition, violent conflict and the power of non-state military 
actors remain key elements of and for strategising in Africa. Indeed, it is possible to argue that strategy, defined as "the use that is made of force and the threat of force for the ends of policy", ${ }^{2}$ in the African security domain often has to confront two parallel challenges: how to promote conflict resolution, post-conflict reconstruction and development on the one hand, and on the other, how to stand up to armed non-state actors when the host government's security forces prove inadequate. $^{3}$

The South African (SA) government views itself and wants to be seen as a net exporter of security in Africa. Since democratisation, South Africa increasingly took up a leading role in conflict prevention, peacekeeping, peace-building and post-conflict reconstruction in the continent. South Africa displays a clear declaratory preference for negotiated settlements through dialogue and consultation with parties. In contrast to this preference, the South African National Defence Force (SANDF) appears to have become a rather prominent vehicle or agency of South Africa's diplomacy towards Africa. The SA military involvement in the Central African Republic (CAR), followed soon by peace enforcement as part of the rapid intervention brigade in the Democratic Republic (DR) of the Congo (2013) and military commitments to the so-called African Capacity for Immediate Response to Crises (ACIRC) force (2014), should be seen in the context of this rather subtle shift from implicit to explicit use of the SA military to export and project security into Africa. Africa, though, has a tendency to become a quagmire for those who force strategies or think they can impose unilateral solutions.

The study on which this article reports, aimed to provide an exposition of SA military strategy in the CAR by means of the strategic equation - strategy equals ends, i.e. objectives toward which one strives, ways, i.e. courses of action, and means, i.e. instruments by which some end can be achieved. ${ }^{4}$ The research question underlying the article originated from a general impression that the event in the CAR where $15 \mathrm{SA}$ soldiers died in clashes with Seleka rebels points towards a military blunder rather than a logical outcome of policy informing military strategy in the pursuit of vital national interests. If military coercion is indicative of defending vital national interests, which interests were so vital in the CAR to activate the military option and sending highly trained combat troops to defend them? This uncertainty frames the primary question, namely which policy imperatives informed the military deployment to the CAR and can this be explained by way of the strategic equation of strategic ends, ways and means?

Responses to the events in Bangui appear to be embedded primarily in government statements, military communiqués, and media responses questioning the politico-military sensibility of decisions and subsequent events. In April 2013, 
in the immediate aftermath of the events, a 40-page publication by Heitman appeared, which largely deals with the unfolding of the battle. ${ }^{5}$ Heitman frames the gap between military means and political expectations, if not ambitions. He emphasises how political preferences not to fund the SANDF properly but to expect them to undertake complex and dangerous missions, eventually culminated in military casualties.

The International Crisis Group (ICG) Report of June 2013 elaborates upon the unfolding events in the CAR over time, but hardly covers the SA involvement. The report is concerned mainly with the regional responses from the surrounding regional actors, but nonetheless notes the aberration of the SA military presence so far removed from its regional sphere, the Southern African Development Community (SADC). ${ }^{6}$ This very matter of geographic distance remains weakly explained by SA political decision-makers and a void in understanding how armed coercion ties in with policy decisions. In October 2013, an Institute for Security Studies (ISS) Policy Brief by Heitman again raised the topic of intervention by generally framing matters on intervention operations into Africa. Heitman compared such interventions with the South African-Bangui experience to highlight that interventions are expensive and complicated and not to be taken lightly. A go-it-alone approach is hardly expected and dangerous to say the least, but this is exactly what transpired with the SA mission to the CAR. ${ }^{7}$

Other literature generally covers opinions and probes through questions related to what happened and requests for enquiries by the media and political actors from the opposition benches over who was at fault. ${ }^{8}$ This crop of literature questions the logic and interests behind the deployment of SA soldiers to the CAR, whether the SA president informed parliament accordingly, why the service provider for strategic airlift did not comply and whether personal interests played a role. ${ }^{9}$ Although in the public domain, this literature set is fragmented and tends to focus on two particular aspects: why exactly did South Africa deploy soldiers to the CAR, and why did this deployment result in the deaths of so many soldiers. Media questions and the political sparring did, however, pay scant attention to questions on military strategy.

Overall, the SA literature does not include matters of strategy. At most, it questions policy decisions, the role of individuals, technical and tactical matters of equipment, social responsibility towards families, and recognition of bravery by the contingents. It also appears that the latter aspects of tactical skills and bravery became a major theme in the media, as well as the dominant narrative from senior officials at the political and military levels of decision-making. ${ }^{10}$ The scale of the media-opposition-government sparring in fact overshadowed any meaningful 
discussion about the policy-strategy interface that placed SA soldiers in the distant CAR.

While the literature on the events in CAR is perhaps not difficult to come by, that which deals with the particular matter of South Africa's military strategy in CAR is glaringly absent or somewhat fragmented in parliamentary questions and responses that tend to be classified information. The latter is visible in the contradiction that the minister stated that all memorandums of understanding (MoUs) are public documents, but the one on the CAR 'suddenly' became a classified document. ${ }^{11}$ One thus has to scrutinise secondary documentation in order to respond to the research question underpinning this article.

The following discussion introduces an outline of South Africa's foreign policy towards Africa followed by a description of the situation in the CAR. The argument then turns towards an analysis of the purpose of SA involvement in the CAR. Next, follows an analysis of South Africa's military capability employed in the CAR with some critical conclusions directed at the SA military course of action.

\section{Africa as primary driver in South African foreign policy}

SA official foreign policy documents provide some context to, understanding of and perspective on South Africa's military involvement in the CAR. Africa seems to shape and define South Africa's foreign policy outlook. Pronouncements by senior political officials of the ruling ANC, political office bearers and SA policy documents are, firstly, quite explicit that Africa is at the centre of South Africa's foreign policy. ${ }^{12}$ Secondly, the need for South Africa to play a leading role "that will promote regional cooperation, peace and security"13 through conflict prevention, peacekeeping, peace-building and post-conflict reconstruction on the African continent is a key guiding principle of South Africa's Department of International Relations and Cooperation (DIRCO). ${ }^{14}$ Thirdly, SA foreign policy guidelines also place a strong emphasis on steering South Africa away from unilateral approaches and actions in Africa towards not only a preference but also a demand or requirement for bilateral and multilateral action. Fourthly, and in line with the preference for bilateral and multilateral action, is a strong policy preference for regional, continental and global political, economic and security structures and actors when engaging with and acting in Africa. South Africa, it is noted for example in DIRCO's strategic plan for 2013-2018, is committed to multilateralism and a rules-based international order, and to this end, promotes global security, sustainable development, human rights and international 
law through its participation in international fora, notably the United Nations (UN) system and its specialised agencies, funds and programmes. ${ }^{15}$

Consequently, South Africa's foreign policy is highly value-driven with its emphasis on Africa's renaissance, good governance, peace and stability. Schoeman describes it as a foreign policy of peace. ${ }^{16}$ However, as Lalbahadur points out, foreign policy decisions are not simply a matter of applying ethics and values. It is also about complex decisions based on the trade-offs between domestic and international imperatives and between short- and long-term interests, mediating and navigating the tension between values and interests. ${ }^{17}$ In the case of South Africa, trade-offs specifically concern the tension between the country's African agenda and its commitment to the promotion of human rights, democracy and the rule of law. This inability to reconcile an inclination towards respect for other countries' sovereignty on the one hand, and towards human rights and democracy on the other, seems to provide some explanation for the evaluation of a general pattern of inconsistency in South Africa's foreign policy. Some argue that this inconsistency tends to erode South Africa's reputation as a regional and continental power whose foreign policy influences events across the continent. ${ }^{18}$

Moreover, South Africa's foreign policy priorities are seen to be ambiguous ${ }^{19}$ with many who are of the opinion that what precisely is directing the country's foreign policy has become obfuscated over time. The storyline seems to run from Nelson Mandela's emphasis on the promotion of human rights, via Thabo Mbeki's anti-colonial, anti-imperialist rhetoric tied to the active pursuit of the African agenda and high involvement in African issues, to confusion, a lack of strategic direction and an inability to envisage and map out a foreign policy correctly under Jacob Zuma. ${ }^{20}$ South Africa's military debacle in the CAR seems to mirror starkly the alleged confusing and inconsistent nature of the country's foreign policy under the Zuma administration. ${ }^{21}$

The inconsistency argument should also be tied to Alden and Schoeman's view that South Africa's foreign policy is constrained by the structural weaknesses of the country's own economy, a declining administrative and political capacity to tap South Africa's resources for strategic purposes, and the legitimacy of its persistent claims to represent Africa's interests. ${ }^{22}$ From a different perspective, it brings the unresolved issue of South Africa's identity, a host of domestic limitations linked to material capabilities and internal politics, and the divided continental reaction to SA leadership into sharp focus. ${ }^{23}$ The contentious appointment of a South African, Nkosazana Dlamini-Zuma, as chairperson of the African Union Commission (AUC) clearly illustrates the point that not all African countries applaud SA stewardship of continental matters. ${ }^{24}$ 
Although foreign policy is almost always about mediating and navigating the tension between values and interests, it remains difficult to discern SA foreign policy interests. Some argue that economic development, security and stability in the region, and peace and conflict resolution within Africa seem to dominate the agenda. ${ }^{25}$ Another view holds that SA interests are defined by a domestically driven material imperative and its external role conceptions - particularly the need to be anti-imperialist, to break the United States' and Western hegemony, and to free Africa from any form of external imperialism. The policy gist seems to be guided by the notion that South Africa should be the 'gateway' to Africa as a secure financial and political platform for exploring economic opportunities in Africa. ${ }^{26}$ Even the country's membership of the Brazil-Russia-India-China-South Africa (BRICS) group of countries is portrayed by President Zuma in terms of the country's assumed position as the gateway into Africa, South Africa's supposed role as the natural leader of Africa, and the country's so-called ability to speak on behalf of the continent as a whole. ${ }^{27}$

Three key considerations thus seem to shape South Africa's approach towards the African continent: the importance of the country's domestic interests; the need to grow African markets for SA goods, and the need for peace and stability in Africa. ${ }^{28}$ Cohen describes this in more realist terms when he argues that SA foreign policy at present "reflects domestic politics: duplicitous, Machiavellian and surrounded by a vague odour of corruption". ${ }^{29}$ This perceived fluid and perhaps uncertain policy environment nonetheless acts as the guiding intelligence for SA decision-makers involved in matters of strategy, and one such decisionmaking hub involves those who must bring the SA armed forces into the policystrategy equation.

The military strategy division of the SA military categorises the whole of Africa as an area of strategic importance, whilst the area that makes up the Southern African Development Community (SADC) is described as an area of strategic influence. A further distinction is made between what is referred to as strategic partners, working partners and symbolic partners. Strategic partnerships are rooted in long-term strategic interests such as South Africa's membership of BRICS and states that constitute important and key interests. Economic relations, such as those with countries in Europe, seem to shape ideas on working partnerships. The most interesting of the categories - and sometimes the most visible - is the symbolic category, relations that are defined by what can be called pragmatic political decisions and debates, and which involve the weaving of historical political considerations into the fabric of foreign relations. For the SA government, these symbolic connections are demarcated by the historical relationships built up during the struggle for liberation in South Africa. The 
countries making up these partnerships often lack strategic resources, are of a geographical position in close proximity to South Africa, or have historical ties dating back to before $1994 .{ }^{30}$ These are relations that, in the view of the ANC government, directly affect South Africa's international standing and prestige. Of course, South Africa's relationship with many countries in Africa is of a symbolic nature. It is historical in nature and driven by the identity of the ruling ANC as a political party demonstrating solidarity in the struggle for Africa's liberation. Historical solidarity, comradeship and shared political worldviews, instead of political, economic and security interests and concerns, are shaping relations in this context. These realities, Hengari argues, "resulted in [the ANC] having less space to pursue a strong regional policy that marries good governance and democracy with South Africa's regional economic agenda". ${ }^{31}$

Thus, and as a matter of irony, South Africa has a strange love-hate relationship with Africa - almost as if the country is not part of Africa and as if South Africa needs to prove its 'Africa-ness'. ${ }^{32}$ In the National Development Plan, for example, it is deemed necessary to declare for some strange reason that "We are Africans [...] We are an African country [...] We are an essential part of our continent." 33 Like many countries from outside Africa, South Africa tends to deal with 'Africa' from a foreign policy perspective as if Africa does not consist of different countries with a huge diversity of nations and peoples, rich and poor, developed and underdeveloped, who have a variety of interests, opinions and prejudices. Moreover, South Africa encourages and enforces this image of Africa in its own search for status and positions in the UN and elsewhere, to be seen as Africa's voice, and as a country that can speak on behalf of Africa. What is often missing from not only the SA political, but also the administrative and bureaucratic spheres, is a nuanced understanding and approach in conceptualising, engaging and dealing with countries in Africa. The SA political approach to Africa seems to be somewhat dogmatic, an Africa-at-all-cost approach that does not necessarily allow for a nuanced and flexible interpretation of South Africa's various interests in specific African countries. It is a conceptual approach that on the surface does not seem to make provision for the fact that South Africa may have political and other types of rivals, competitors and even enemies in Africa.

This inconvenient truth was physically, hard and clearly demonstrated by the undeniable reality of the casualty list in the March 2013 Battle of Bangui. South Africa's African foreign policy perspective and approach, thus, often seem to be based on the naïve assumption that South Africa, like Nelson Mandela, is welcomed with enthusiasm and open arms by every single individual and country in 'Africa'. ${ }^{34}$ It is possible to argue that this is not a policy approach that often eschews judgement in application. The motto seems to be 'Africa at all costs'. 
The emphasis on peace and security in Africa in the strategic documents of both DIRCO and the Department of Defence and Military Veterans (DoDMV), by definition, underlines the military as an important instrument of South Africa's foreign policy in Africa. The recently published Defence Review, specifically, makes provision for a layered defence approach as a driver of South Africa's military strategy. The first layer defines the need to influence the international security agenda through integrated diplomacy efforts and the pursuit of national objectives. It also highlights the need for strategic engagement of the UN and the African Peace and Security Architecture, to pursue defined multi-lateral security objectives, promote the deepening of democracy on the African continent, and promote peace, security and development on the continent. However, it also outlines the need to pursue "... strategic bi-lateral objectives". The second layer refers to the need to 'safeguard' the SA people and the country's territory, to protect vital SA national interests "collaboratively or deliberately", and to contribute to South Africa's developmental agenda. The third layer highlights the importance to "... defend and protect the territory, sovereignty and people of the Republic of South Africa". ${ }^{35}$ Threats closer to home seem to bring a preference for armed coercion to the fore, whilst the approach to the outer layers seems to rely much more on softer constructive roles and collaborative ways.

\section{Entering the cauldron: Instability in the Central African Republic}

Since the events of March 2013, now commonly known as 'the Battle of Bangui' when SA forces met in battle with Seleka rebels in the capital city of the CAR, the country lapsed back into what can be typically termed 'war amongst the people'. ${ }^{36}$ The image of anarchy in the CAR emerges in the absence of any meaningful central government offering some resemblance of security as a political good to serve as a catalyst for good governance. Since the Battle of Bangui, a new and rather extensive wave of external intervention missions in the CAR took shape that for all practical purposes are the only barriers to total internal collapse. For some observers, this image of the CAR could well be 'business as usual', but the pattern of events since January 2013 flags some important aspects to consider.

From an SA perspective, the clash between SA soldiers based in Bangui and rebel forces was a military battle between two opposing armed forces brought about by two widely differing sets of objectives. The SA military contingents in the CAR emerged from a little-understood SA-CAR MoU on military cooperation signed in February 2007. ${ }^{37}$ The Seleka rebel forces stem from fluid and unpredictable politics that characterise the region - also called 'the tormented triangle' - that give rise to a persistent proliferation of non-state armed groups 
rising, splintering and merging in and around the CAR. In essence, the SANDFSeleka battle in Bangui represents opposing interests broadly portraying traditional against non-traditional interests: state interests pitted against personal-group interests clothed in heavily armed and externally supported rebel contingents. At the minimum, this is a representation of a challenge posed by heavily armed nonstate groups to the status quo pursued by African states. Of course, in the case of the CAR, France has often aided incumbent governments against rebels, as successive CAR governments were all unable to safeguard the country's borders and its people. ${ }^{38}$

From a level of analysis point of view, the CAR is an African sovereign state that finds itself at the mercy of actors such as rebel groups operating below the level of the state, actors at state level like France, South Africa, and Chad, and entities above the state as embodied by the Economic Community of Central African States (ECCAS) and the African Union (AU). The pressures and influences from all three levels simultaneously affect the CAR with the country being in no position to stave off armed threats or deal with the outfall in any constructive manner. As a result, entities other than the CAR government have become main players in the CAR's domestic landscape.

Studies on the CAR often portray the country as a weak and fragile state whether explicitly or implicitly. On the weak state index (now fragile states) of the Fund for Peace employing socio-economic and politico-military indicators, the CAR hovers at an index of approximately 105.3/120 and number 9/178 while being flagged as a high alert case. The CAR also persisted in the top 10 rankings of fragility since 2007 . The country showed, in addition, the worst decline in score for 2014 when it dropped from 105.3 (2013) down to 110.6 (2014) while reflecting the most significant shift towards more weakness out of 178 countries. The CAR furthermore regressed in the alert category from position 9 (2013) to position 3 (2014) and so entered the very high alert category of fragile states in the international system. By 2013/2014, the CAR thus assumed the most serious levels of weakness and fragility according to the Fund for Peace index. ${ }^{39}$

Weak states reflect a certain security dynamic in the sense that they fall victim to internal and external threats and vulnerabilities. The collective outcome is the failure to provide political goods to society, which acts as a catalyst for rising internal frustration and anger. Robert Rotberg outlines these matters in a specific manner. He argues that it is not the intensity, but the enduring nature of violence directed at the governing authorities that indicates weakness and failure. ${ }^{40}$ In the case of the CAR, this cycle of violence commenced after independence in 1960 and still persists today with the period 2013/2014 perhaps reflecting the pinnacle 
with references to genocide and a collapsed state being uttered. ${ }^{41}$ Mehler offers an overview depicting continuous internal strife, mutinies, interventions and rebellion to contest political power reaching back to $1965 .{ }^{42}$ Since 2010 , the CAR lapsed into even worse internal strife with the rise of the Seleka rebel group coexisting with about seven other armed groups in the CAR, each fighting the central government on its own terms and agendas. ${ }^{43}$

In the CAR, violence seems to stem from ethnic, religious and linguistic differences, and becomes more accentuated when one considers how resources enter the fray of competing groups. ${ }^{44}$ The history of internal armed strife broadly depicts conflict often unfolding along ethnic and religious fault lines. While earlier conflict profiles show a strong ethnic slant, events since February 2013 reflect an ominous religious divide. Ethnicity became an early tool of the divide-and-rule principle in CAR politics as different rulers used it to bolster their respective regimes. As leaders, Bozize used the Gbaya, Kolingba used the Yakoma, while the earlier ruler Patasse again rooted out the Yakoma factor in the security forces in particular to break the ethnic nexus and loyalty to his predecessor. ${ }^{45}$ Religion became particularly salient during 2013/2014 as the Seleka rebels extended their influence. The Seleka group is labelled 'pro-Muslim' and in response, the antiBalaka group emerged as a Christian counter to the plundering by the Seleka rebels. As a result, on 29 March 2014 for example, 24 civilians were killed when Chadian soldiers escorting Muslims opened fire in response to a suspected antiBalaka attack. ${ }^{46}$ The Balakas also stand accused of siding with the Lord's Resistance Army (LRA) from Uganda and, as such, religious battle lines were drawn between Muslim and Christian factions while in addition, the LRA is already on the international list of terrorist organisations.

An inability to control borders and the loss of tracts of national territory to opposition forces place more pressure on authorities already weakened by an inability to implement policies to extend governance. ${ }^{47}$ The northeastern border regions between the CAR and the Sudan and between the Sudan, CAR and Chad are typical of transition zones where the local communities have little in common with their national centres of power. Weak border management leads to the flow of military material, small arms, migration of fighters and organised crime. ${ }^{48}$ Concerning the loss of control over territory, Human Rights Watch pointed out how the Selekas regrouped in the northeast of the CAR to continue their rampage in the face of no government response to counter such mobilisation. ${ }^{49}$ In addition, even during earlier times, anti-Deby rebels from Chad merely used the northeastern part of the CAR as transit area between the Sudan and Chad in an attempt to unsettle the regime of Deby, ruler of Chad. ${ }^{50}$ As for the battle between the SA forces and the Seleka forces, it is not surprising that the latter mobilised and moved 
unopposed by road up to the outskirts of Bangui where the SA military contingent offered the first meaningful resistance to their advance.

In the CAR, the use of national and rebel security contingents by rulers became a pathway to maintain or contest power, but raised parallel threats to society. Predatory practices aimed at own communities and the growth of criminal violence combine to foster a general climate of lawlessness. Oppression and resort to coercion then becomes the standard response of government to threats and vulnerabilities. ${ }^{51}$ Amnesty International outlines atrocities by both the Bozize loyalists and the Selekas against civilians and those deemed opponents to their quest for political power while the incumbent government appeared helpless or unwilling to step in. ${ }^{52}$ As such, Amnesty International accuses successive governments and rebel opponents like Seleka of practices amounting to human rights violations by using armed violence against civilians in pursuit of power in Bangui, as well as in the surrounding countryside. Unfortunately, neither the rebel movement, nor the ousted regime or the incumbent government offers any hope of human security to the CAR society and protests to claim universal public goods are met with further force and violence from the rulers.

The internal weakness of CAR is accentuated and exploited by actors sharing its regional setting that harbours what one could call 'a rough neighbourhood'. Chad is viewed as a major player in the CAR instability, and the 2013 advance of the Seleka rebels in particular, ${ }^{53}$ but the setting for the fragility of the CAR reaches beyond Chad. Sudan, Chad and the CAR reflect a dynamic akin to the view of Barry Buzan that their security and insecurity can hardly be considered in isolation and in fact took shape as a regional conflict formation. Giroux, Lanz and Sguaitamatti refer to the tormented triangle represented by Chad, the Sudan and the CAR where the regional conflict dynamics are also heavily influenced by internal dynamics of the surrounding states. ${ }^{54}$ To the south, the Democratic Republic of the Congo (hereafter DR Congo) also comes into play, as a rebel movement from its volatile eastern region also entered the fray in 2002 to assist former ruler Patasse against the advancing forces of Bozize who eventually took power by overthrowing Patasse. There was also a prominent Chadian mercenary element in Bangui to assist with the overthrow and maintenance of power. Later, Bozize could not keep rebels at bay without French and Chadian forces (i.e. in November 2006). Amnesty International draws an intricate network of Chadian, Sudanese, Ugandan, Congolese, French and SA involvement in the CAR, presumably in support of the central authorities with the latter being challenged by an equally intricate collection of rebel forces with unpredictable and fluid loyalties reaching into CAR society, but also outwards to neighbouring regimes. ${ }^{55}$ 
For the purpose of this article, the above brings into focus two important matters. Firstly, the response or combination of responses most appropriate, given the argument that African conflicts tend to overwhelm those attempting to impose unilateral solutions, and secondly, the role of armed forces given the salience of the military option in the case of CAR. Regarding the most appropriate options to restore order and governance, Rotberg warns that revival of a weak and collapsing state is almost not an option. ${ }^{56}$ Even the better option of strengthening the state to prevent collapse is difficult, expensive and of long duration. It is however, within the rebuilding of security to support civil society and governance that the core or catalyst of revival resides. Here the argument links security establishments with rebuilding and strengthening. But, under closer scrutiny, the nexus between the rebuilding of military and security institutions shows a particular dynamic that is a conundrum rather than a credible solution. This is because many of the military contingents at play in the CAR contribute to rather than resolve its security dilemma.

In the case of the CAR, the country's security forces were central to the insecurity faced by society and the country in general. Not only coups, but mutinying factions and human rights violations, soldiers turning rebels and special personal military contingents and guards for elite protection characterise the profile of the CAR's military forces (les Forces armées centrafricaines or FACA). Mehler outlines the reasons for FACA not functioning to contribute to the first political good of security: a collapsed security system, a patchwork-like composition of security forces, destroyed infrastructure, a lack of equipment, a lack of qualified, fit and trained personnel, and a dysfunctional chain of command. ${ }^{57}$ As such, FACA was unable to function, as the armed forces of the CAR enjoyed no real legitimacy, competed with private and rebel military contingents, and as such stopped to serve as a policy instrument of the central government. The aforementioned weakness of the CAR security forces became the presumed catalyst for SA military involvement with the idea to train and set CAR forces on a more professional footing. ${ }^{58}$ Their presence also led to the eventual clash between members of the SANDF and the Seleka rebels in and around Bangui in March 2013. Against this backdrop of almost no ways and means in the CAR to extend even basic security governance, the following discussion sets the Battle of Bangui within the context of SA policy and the elements of strategy.

\section{The South African political-military nexus in the Central African Republic}

For professional militaries, including the SA military, it is important to ensure a Clausewitzian logic in the conduct of operations. More specifically, 
militaries need to operationalise foreign policy in general and specific foreign policy objectives in particular through the establishment of the nexus between specific national interests, military deployments and the use of force. The debate that followed on the deployment of the military to the CAR in 2007, and the resultant events in Bangui in March 2013 in which 15 SA paratroopers were killed, serve to prove this point. ${ }^{59}$ SA military deployments into Africa are informed by the basic political assumption of African unity that leads to the defence question of against whom we are we defending. The inability to answer this question often means that from a tactical and operational perspective, the SANDF is deploying lightly armed and poorly supported troops into volatile countries, often without heavy weapons or support. It was, thus, interesting to note how the SA forces that were deployed into the DR Congo in the immediate aftermath of the incident in the CAR were 'up-gunned' with the first-time deployment of Rooivalk attack helicopters. ${ }^{60}$

A fundamental challenge in SA military operations, though, is the absence of a comprehensive and clearly articulated national security strategy. ${ }^{61}$ From a civil-military perspective, this means that deployments, such as the one to the CAR, cannot be justified under the banner of such a strategy or be criticised on grounds of these operations being in contradiction to the policy or strategy. Of course, it is possible to argue that some governments tend to be vague in this regard precisely because being vague provides them with increased freedom of action. Whether that is the case in South Africa, is doubtful. What materialises instead is "a haphazard, scatter-gun approach that invokes our national interests when convenient, and simply ignores it when it's not". ${ }^{62}$ When it is difficult to find the logic and to establish the link between military deployments and the protection or extension of clearly articulated national interests, military deployments become a civil-military issue. When this is augmented by a perceived urgent need for domestic military priorities in areas like border protection or counter-poaching and crime-related operations, ${ }^{63}$ society tends to look towards the military as an extension of the interests of the executive and its associates - not of Parliament or the people of the country in general. In Africa, as is elsewhere the case, domestic deployments are by custom concrete and indubitable and do not necessarily require comprehensive justification from the executive branch of government and legalisation from the legislative branch. Foreign deployments, in contrast, necessitate both justification and legalisation by means of the protection or extension of discernible national interests.

The fact that the role of the military in Africa seems to have morphed from the established model of supporting strongmen to that of protecting and projecting economic power and influence brought SA military involvement in the CAR into 
sharp focus ${ }^{64}$ Explanations by the SA executive regarding the purported bilateral agreement that was supposed to legitimise the SA military involvement in the CAR are unconvincing and inadequate. The key question is not only whether the SA military presence in the CAR was legitimate but, rather, whether it was morally defensible in view of South Africa's apparent support for an illegitimate regime in order to protect what seemed to be economic interests with strong links to powerful domestic political networks. ${ }^{65}$

There were many allegations and much speculation that the SA intervention in the CAR was to protect private SA business interests that were closely linked to the presidency. ${ }^{66}$ More recently, this speculation seems to have been substantiated ${ }^{67}$ At the time, though, this was strongly denied by the SA president with arguments that South Africa intervened in the interest of the safety, stability and security of the region. ${ }^{68}$ That begs the question - why only in 2013 after a decade of turmoil in the CAR and the DR Congo, and through unilateral action that excluded the SADC, the AU and ECCAS? Obviously, the CAR adjoins the DR Congo, and South Africa may have feared that instability in the CAR would spread to the DR Congo. The DR Congo, unlike the CAR, is a member of the SADC, but strangely, South Africa has no embassy or diplomatic presence in the CAR, which casts some doubt upon the suddenly declared importance of the CAR in SA's foreign policy ${ }^{69}$ In a sense, this inconsistency harks back to the view above by Stupart of the SA government invoking national interests when convenient.

In a briefing in Parliament on 3 April 2013, the Minister of Defence and Military Veterans highlighted that the SA deployment to the CAR was based on a bilateral MoU between the governments of South Africa and the CAR. Although the SA government refused to make the MoU public after the death of the South Africa soldiers in March 2013, the aim of the deployment seems to have been to assist with capacity building in the CAR. The MoU was signed in the context of the 2007 peace deal under the auspices of the AU between the CAR government and the rebel movements. The SA forces were to lead the process of integration of the armed forces. Military training was to be provided for very important person (VIP) protection and infantry soldiers whilst they were also supposed to provide equipment and uniforms, and refurbish bases. The MoU was renewed in December 2012. With the deterioration of the security situation in 2012, South Africa deployed a 'security force' for the small training establishment and military equipment already positioned in the CAR. ${ }^{70}$ The additional soldiers, the minister emphasised, were not trainers. These soldiers were in fact from the parachute and special force regiments, which raised further questions about the employment of such highly specialised soldiers as a protection element. The minister also 
highlighted in the briefing some disturbing developments in that after a seven-year training mission:

- It was impossible to withdraw the training establishment of 26 trainers with their equipment and vehicles;

- $\quad$ There was a steady decline in the number of people in the CAR that were being trained; and

- There was uncertainty about the whereabouts of some of the CAR citizens that had been trained.

Of great interest was the remark by the minister that the renewing of the MoU in 2012 was underpinned by the task "to protect the leadership of the country". She also noted that the European Union (EU) representative called on the SANDF not to withdraw due to the tense and fragile situation in the country. Thus, the minister noted, "there was a history of coups. Instability could not be allowed, Rebels could not be allowed to overthrow the government. This was why RSA [i.e. South Africa] had led the process of demobilisation and re-integration". ${ }^{71}$

Opposition parties were quick to point towards the discrepancy in the explanations by the president, the responsible minister, and the chief of the SANDF. More specifically, they pointed towards the president's explanation to Parliament in two letters. The first explained that the SANDF was employed to "assist with capacity building of the CAR Defence Force and [to] assist that country with planning and implementation of the disarmament, demobilisation and reintegration process". ${ }^{72}$ The president noted in a second letter, "this employment will run up to the end of the duration of our MoU (memorandum of understanding), however if the situation improves in the intervening period, we will revise the protection element". ${ }^{73}$ The neglect to make the contents of the MoU public, together with the wide explanation as to why SA was militarily involved in the CAR, opened the door for speculation, criticism, and doubt by society.

In view of the general approach to foreign policy by the SA government, the real question concerning SA involvement in the CAR was why, if SA was to be involved in a military intervention in CAR, it did not take place under the umbrella of SADC, the AU or any other multilateral security structure and with the consent or agreement of ECCAS. Or, did the situation that unfolded in the CAR highlight the failure of the African security architecture, specifically its drive towards the creation of an African standby and rapid intervention capability ${ }^{74}$ Why did South Africa - in the immediate aftermath of the incident in CAR in May 2013 - ask the AU for the creation of a new force, to be known as the ACIRC? This question is even more significant in the context of the immediate shift from South Africa's unilateral military involvement in the CAR to its drive for a leading role in the 
deployment of an intervention brigade of SADC soldiers within the UN Organization Stabilization Mission in DR Congo (MONUSCO) to carry out targeted offensive operations against armed groups, such as the M23 rebels, that threatened peace in the DR Congo. At the time, the immediate SA involvement in the DR Congo seemed be a diversionary tactic in shifting media and societal attention away from the CAR incident. What it did not obscure, was the growing emphasis upon using the country's armed forces as a leading policy instrument.

The sudden prominence of South Africa in newly configured African response mechanisms might be encouraging, but given the military profile of such initiatives, it brings into focus the standing of the armed forces. South Africa's armed forces seem to find themselves at a crucial crossroad at a time when the political expectations of the military as a foreign policy instrument appear to be at its zenith.

\section{South African military capability: Dysfunctions and over-commitments}

The 2014 Defence Review highlights the need for the SANDF to maintain the military capabilities to ensure the:

- Freedom of South Africa to trade, including the free use of land, air and sea routes, good order at sea and in the airspace, and the safety and security of trade and transport hubs;

- Security, domestically and externally, of fundamental resources, such as minerals, energy and water, including the safe and secure delivery, processing and distribution thereof;

- Safety and security of domestic and external strategic installations; and

- Safety and security of the SA people, both within national territory and abroad. $^{75}$

In view of these specific tasks, and from a strategic perspective, the SA military should be capable of fulfilling three key functions and roles. It should firstly be able to deter possible external threats and to deal decisively with those threats if they emerge. Secondly, unlike most developed states and mature democracies, but very much in line with the responsibilities of militaries in most developed countries, the SA military should be capable of performing internal stability tasks almost permanently. In the case of the SANDF, this typically includes border protection, anti-poaching operations, support to the police in the fight against crime and general support to the population in cataclysmic times of upheaval and disaster. Thirdly, South Africa's position as a hegemon in Africa, linked to its international commitments as a regional power to play a key role in the stability, safety and security of the region and the continent, necessitates a military 
capability to project and participate in peace and stability operations in the region and the continent.

In reflecting on these capabilities, it is quite clear that the requirement for deterrence and the warfighting capability that underpins the need, necessitates a much heavier and more robust force than what is needed for internal stability and force projection. The internal stability and force projection capability, in contrast, is predominantly of a light, mostly infantry and rapid reaction nature. It is this discrepancy that Schoeman had in mind when she noted that, in an era of austerity, militaries find themselves hard-pressed to fulfil the dual role of conventional preparedness to defend national security and interests and to provide support to international commitments. ${ }^{76}$ The capability requirements are exacerbated by the inverse relationship between intensity and frequency in the conduct of these divergent missions. Air superiority, armour and artillery may be key capabilities for deterrence. Besides, infantry, internal stability and force projection cannot be done without sound strategic airlift, agile and sustainable logistics and good $\mathrm{C}^{3} \mathrm{I}$ (i.e. command, control, communications and intelligence). ${ }^{77}$

Two factors that are of key strategic importance for South Africa's strategic outlook and which speak directly to its military capability were highlighted by the Minister of Defence and Military Veterans in her 2014 Defence Budget speech in the aftermath of the Bangui debacle. Firstly, she pointed out that, at the time, the Department and, by implication the SANDF, were overextended "... by a host of events nationally, regionally, continentally, and internationally". ${ }^{78}$ Of course, central to these complex activities was the heavy involvement of the military in the stability, peace and security of specific countries in Africa. Secondly, at the time, the SANDF was in a serious state of decline characterised by force imbalances between capabilities, ageing technology, and the unaffordability of many of its main operating systems. Her view that "... the decline will get worse" was of even greater concern. ${ }^{79}$ In fact, even before the March 2013 Battle of Bangui, certain analysts expressed the harsh view that "... South Africa's government has so neglected or mismanaged its military assets that it may soon be unable to defend itself, much less engage in international adventures" and "... the steady transformation of the SANDF into an assembly of riot police and border guards will be completed in just a few years". ${ }^{80}$ Needless to say, these alarming factors about South Africa's military forces did not arise overnight and served as an influential, albeit ignored backdrop to the decision to escalate SANDF forces in the CAR over the period December 2012 to March 2013. 
Against the context of the comprehensive needs and demands from various actors for constructive involvement by the SA military, which underpins its overextension, the minister highlighted the need to -

- $\quad$ arrest the decline in the SANDF;

- rebalance the force through a process of reprioritising;

- $\quad$ ensure capacity for the existing and current needs;

- develop capacity to meet future challenges; and

- $\quad$ build the strength of the SANDF to engage in limited warfighting if such a need should arise. ${ }^{81}$

Nowhere was the acknowledged decline and lack of capacity as clearly demonstrated at the operational level as in the case of the CAR deployment.

This is not the place to lambast the SA military again for its alleged general decline and dismal nature of its capabilities, its dysfunctional institutional culture, its general and widespread lack of discipline and leadership, and its lack of understanding by society. One only has to read the budget speeches of the Ministers of Defence and Military Veterans over the last more than ten years to gain some insight into the challenges confronting the military - and how warnings became more accentuated over time, and culminating in the brusque 2014 open speech by the incumbent minister on the state of the SANDF. The majority of the problems of the SANDF can be explained within the context of the history of the SA society in general and the military's institutional roots in the anti-apartheid revolutionary movements and history of integration. This links to the disastrous decrease in the defence budget since 1994 to address SA welfare and social needs. The decrease in the defence budget was accentuated by the simultaneous growing demand for and employment of the SANDF. Many of the problems within the SANDF, of course, are not related to the budget and tend to be underpinned by challenges pertaining to institutional, cultural, leadership, discipline and a range of personnel dysfunctions that are complex and multidimensional, with widespectrum and multi-layered implications. ${ }^{82}$

Of greater concern is the lack of political will and military expertise to rectify and address the spectrum of problems that underpins the SANDF's effectiveness and capabilities. ${ }^{83}$ As is clearly demonstrated in the 2014 Budget Speech of the Minister of Defence and Military Veterans, there seems to be a cold and clinical political recognition of the decline of the military function. The drive to rectify and address the key problems, however, can only be described in terms of incrementalism and tokenism. There is, in short, a lot of noise about the problem but few signals that anything tangible is being done. For the most part, the military 
in Pretoria relies on crisis management and a scramble approach whenever new demands for military deployment are placed upon them. ${ }^{84}$

Turning to the operation in the CAR, the SA forces in the CAR were not only too small and patently outnumbered, but confusion in the chain of command and the inability of the SA military to support its forces in the theatre of operation also had disastrous consequences. ${ }^{85}$ More specifically, the forces in the CAR eventually found themselves in a position in which no soldier wants to be. ${ }^{86}$ They were, for all practical purposes 'blind', with only a limited tactical intelligence capability on the ground and no reliable operational and strategic intelligence capability from Pretoria in support. The clear strategic indicators that were available to Pretoria about the unfolding of the crisis appeared to have been ignored. ${ }^{87}$ In retrospect, the Minister and the generals provided a somewhat naïve and almost conspiracy-driven outline of precisely how the situation in the CAR unfolded. The minister in this regard noted in her briefing to Parliament that:

... such an attack had never been anticipated, there had been accusations of poor intelligence, nor was the base geared to repel an attack on such a scale. This might have been a naïve approach. The SANDF had never anticipated becoming involved in the conflict. The mandate had never changed. $^{88}$

In the CAR itself, the forces not only operated almost blindly; the force commander, as a colonel, also had no staff system to support him and South Africa had no diplomatic presence to provide diplomatic support and intelligence to link up with the French and influential neighbouring countries such as Chad. ${ }^{89}$ In effect, one could ask how such a state of affairs arose if there was any credible policystrategy logic between foreign affairs and defence to employ armed coercion as a way to defend national interests.

Of greater concern was the SANDF's lack of strategic airlift to either reinforce or withdraw the SA forces from the CAR. As a result, the forces had no medical support beside the small but professional medical contingent attached to the forces or the ability to evacuate the wounded and casualties from the combat area. Needless to say, armed with only small arms, the forces operated without any close air support or larger calibre indirect fire support systems. The lack of strategic airlift also meant that the SANDF was challenged in its second-line capacity to support and reinforce the forces in the CAR logistically. Thus, from a doctrinal perspective, it is important to question the employment of lightly armed parachute forces without the ability to reinforce such forces with heavier capabilities within a short period of time, and also the employment of reconnaissance-oriented Special Forces in a semi-conventional capacity for which 
they are not equipped and, one may argue, not trained. On a higher level, whether out of principle or because of the general aversion of the SA government to work with the West and previous colonial powers, or because of a clash of interests, the SA forces did not cultivate the help of the French forces that were also deployed in the area. The best the French could do was to provide a guard of honour for the deceased South Africa soldiers being carried into the aircraft on their way back home.

\section{Conclusion}

Strategy, orchestrating the interplay between political ends and coercive means, served as a broad outline for addressing the SA military involvement in CAR. The following concluding remarks are therefore set within the outcomes and objectives, policy-related guides for decisions and actions and the operation of human resources and material assets that make up the logic of strategy. Here it is important to note that the norm of a SA military strategy to serve as a measurement for ends, ways and means in the case of CAR, hardly existed in this particular case. At most, the emergent Defence Review offers some guidance, and this is perhaps most visible in the frank responses of the defence minister.

Concerning the outcomes sought, the CAR is a weak state that finds itself at a level of fragility where arresting the decline is barely within the collective, and even less so the unilateral capabilities of actors who seek a turn-around. South Africa thus had little prospect of arresting the decline in CAR through its unilateral initiative. At the minimum, failure is demonstrated by the absence of any meaningful turnaround in the CAR armed forces where South Africa focused most of its political and military resources for the preceding six years. The CAR forces (in spite of being the primary rationale for the governing MoU) played no role when asked to do battle against the Seleka rebels.

When considering the means, SA foreign policy did not map out a clear pathway for bringing in the SANDF as a policy instrument, but the SANDF nonetheless became a prominent feature of the country's foreign policy into Africa, which suggests some disequilibrium in the ways sought to pursue policy. The optimism of assisting in resolving dangerous African conflicts soon became tempered by repeated political and military warnings against a trend of escalating commitments. The CAR endeavour also demonstrated the gulf that developed between idealistic policy outlooks and the elements of strategy, both of which have to inform the kind of forces that South Africa had to prepare, train and equip in order to respond with credible military means to the growing policy demands for military diplomacy. It is not surprising that in the midst of the 2014 Defence 
Review and the incumbent minister's frank views, the persistent warnings about the decline of the SANDF was preceded by the alarming events in the CAR where SA soldiers fought bravely, but without the guiding intelligence of well-considered political and military backing to which they were entitled.

From both strategic and policy perspectives, SA military involvement in the CAR registered close to zero on the scale of strategic outcome and effectiveness. In many mature democracies, such catastrophic strategic failure, probably would have toppled the government. Although the SA government and the SANDF were quick to highlight the skills, bravery and commitment of the SA soldiers (and rightly so) at grassroots level, the lessons to be learned from the failure all seem to be of a negative operational and strategic nature. More specifically, it is a case study of, firstly, how not to direct operations from a political and strategic perspective. Secondly, it speaks volumes of how not to resource operations that are beyond the operational and strategic reach of the armed forces. In combination, these two factors merge neatly to corroborate the forthright views of the 2014 Defence Review and the incumbent defence minister on the strategic ineptitude, inability and failure of contemporary strategy and SA strategic actors.

\section{Endnotes}

${ }^{1}$ See J Cilliers \& J Schünemann. The future of intrastate conflict in Africa: More violence or greater peace? ISS paper 246. May 2013, for an exposition of the reasons of conflict in Africa.

${ }^{2}$ CS Gray. Modern strategy. Oxford: Oxford University Press, 1999, 17.

${ }^{3}$ PD Williams. "Peace operations in Africa: Lessons learned since 2000". Africa Security Brief 25. July 2013. 1.

${ }^{4}$ AF Lykke. "Defining military strategy". Military Review. May 1989. 2-8. Reprinted in the January/February 1997 edition of Military Review.

${ }^{5}$ H Römer Heitman. The Battle in Bangui: The untold inside story. Johannesburg: Parktown Publishers, 2013.

${ }^{6}$ International Crisis Group. "Central African Republic: Priorities for the transition". Crisis Group Africa Report No. 203. Brussels: International Crisis Group Headquarters. 11 June 2013. 10.

<http://www.crisisgroup.org/ /media/Files/africa/central-africa/centralafrican-republic/203-central-african-republic-priorities-of-the-transition.pdf> Accessed on 6 April 2016.

${ }^{7} \mathrm{H}$ Römer Heitman. Fighting for peace: Offensive intervention to make peace support possible. ISS policy brief 45. October 2013. 
${ }^{8}$ Parliamentary Monitoring Group. "Defence Minister on Central African Republic soldier deployment”. 3 April 2013. < $\underline{\text { https://pmg.org.za/committee- }}$ meeting/15658/> Accessed on 1 December 2016.

${ }^{9}$ A McGregor. "South African Military disaster in the Central African Republic: Part One, The rebel offensive". TerrorismMonitor XI. 7. 4 April 2013. 2; A McGregor. "South African military disaster in the Central African Republic, Part two: The political and strategic fallout". TerrorismMonitor XI. 7. 4 April 2013. 3. 〈http://www.jamestown.org/uploads/media/TM_011_Issue07_02.pdf $>$ Accessed on 6 April 2016.

${ }^{10} \mathrm{~K}$ Helfrich. "Still no answers on the battle for Bangui". defenceWeb. 21 August 2014.

<http://www.defenceweb.co.za/index.php?option=com_content\&view=articl e\&id=35937: still-no-answers-on-the-battle-for-bangui\&catid=111:sadefence> Accessed on 6 April 2016.

${ }^{11}$ Parliamentary Monitoring Group op. cit.

.${ }^{12}$ South African Department of International Relations and Cooperation. "Strategic Plan 2013-2018”. 2. <http://www.dfa.gov.za/department/strategic_plan_20132018/strategic_plan_2013-2018.pdf Accessed on 1 December 2016.

${ }^{13}$ See AT Hengari. South Africa's regional policy: The link between normative anchors and economic diplomacy in SADC. Occasional paper no. 186. South African Institute for International Affairs. May 2014. 8-9 for an outline of South African successes in this regard.

<http://www.saiia.org.za/doc_download/560-south-africa-s-regional-policythe-link-between-normative-anchors-and-economic-diplomacy-in-sadc> Accessed on 22 October 2014.

${ }^{14}$ South African Department of International Relations and Cooperation op. cit. 15 Ibid.

${ }^{16}$ M Schoeman. "Foreign policy and the Military". In T Neethling \& H Hudson (eds), Post-conflict reconstruction and development in Africa: Concepts, role-players, policy and practice, Cape Town: UCT Press, 2013, 214.

${ }^{17}$ A Lalbahadur. Moving beyond 'trophy diplomacy': How to consolidate South Africa's position in the world. SAIIA South African Foreign Policy Perception Survey. <http://www.saiia.org.za/opinion-analysis/movingbeyond-trophy-diplomacy-how-to-consolidate-south-africas-position-in-theworld> Accessed on 1 December 2016.

18 A Dudley. South Africa's foreign policy: Striving towards Mandela's ideals. Policy brief no. 89. Africa Institute of South Africa, June 2013, 2, 4. 
${ }^{19}$ C Saunders. "South Africa and Africa". The ANNALS of the American Academy of Political and Social Science 652. 2014. 222.

${ }^{20}$ Lalbahadur op. cit.

${ }^{21}$ See ibid. for a comprehensive outline of the inconsistencies in South African foreign policy.

${ }^{22}$ C Alden \& M Schoeman. "South Africa in the company of giants: The search for leadership in a transforming global order". International Affairs 89. 1. 2013. 119-120.

23 Ibid., p. 111.

${ }^{24}$ A Maasho. "Dlamini-Zuma elected to head AU Commission". Mail and Guardian: Africa. 16 July 2012. <http://mg.co.za/article/2012-07-16dlamini-zuma-elected-to-head-au-commission $>$ Accessed on 4 November 2015.

${ }^{25}$ Lalbahadur op. cit.

${ }^{26}$ Alden \& Schoeman op. cit., pp. 118-119.

${ }^{27}$ Saunders op. cit., p. 230.

${ }^{28}$ Ibid., p. 233.

${ }^{29}$ T Cohen. "Wheel of foreign policy has turned full circle". Business Day Live. 4 April 2013. <http://www.bdlive.co.za/opinion/columnists/2013/04/04/wheelof-foreign-policy-has-turned-full-circle> Accessed on 13 June 2014.

30 See Hengari op. cit., pp. 10-13 for an outline of South Africa's approaches in this regard.

${ }^{31}$ Ibid., p. 14.

${ }^{32}$ Saunders op. cit., p. 222.

${ }^{33}$ National Planning Commission. "National Development Plan: Vision for 2030". 11 November 2011. 42. <http://www.gov.za/issues/national-developmentplan/> Accessed on 28 July 2014.

35 South African Government Online. "South African Defence Review 2014". 25 March 2014. 3-10. 〈http://www.gov.za/documents/detail.php?cid=402524> Accessed on 14 April 2014.

${ }^{36} \mathrm{R}$ Smith. The utility of force: The art of war in the modern world. New York, NY: Vintage, 2008 (reprint ed.).

${ }^{37}$ Parliamentary Monitoring Group op. cit.

38 V Darracq. "France in Central Africa: The reluctant interventionist". Al Jazeera Opinion. 11 February 2014.

<http://www.aljazeera.com/indepth/opinion/2014/02/france-central-africareluctant--20142975859862140.html> Accessed on 4 November 2015.

${ }^{39}$ Fund for Peace. Failed States Index: IX 2013. Washington, DC, 4-5. 
${ }^{40}$ RI Rotberg. "The new nature of nation state failure". The Washington Quarterly 25/3. 2002. 85 .

41 A de Waal. "Playing the genocide card". The New York Times. 18 December 2013. <http://www.nytimes.com/2013/12/19/opinion/playing-the-genocidecard.html?hpw\&rref=opinion\&_r=0> Accessed on 5 June 2014.

42 A Mehler. "Why security forces do not deliver security: Evidence from Liberia and the Central African Republic". Armed Forces and Society 38/1. 2012. 53.

${ }^{43}$ S Herbert, S Dukhan \& M Debos. State fragility in the Central African Republic: What prompted the 2013 coup? Rapid literature review. Birmingham: GSDRC, University of Birmingham, July 2013, 5.

${ }^{44}$ Rotberg op. cit., p. 86.

${ }^{45}$ Mehler op. cit., pp. 53-55.

${ }^{46}$ African Armed Forces. "CAR: Chadian soldiers fire on civilians; LRA joins antiBalaka”. AAFOnline. 1 April 2014. <http://www.aafonline.co.za/news/carchadian-soldiers-fire-civilians-lra-joins-anti-balaka> 4 June 2014.

${ }^{47}$ Rotberg op. cit., p. 86.

${ }^{48}$ Herbert et al. op cit., p. 12.

${ }^{49}$ Human Rights Watch. "Central African Republic: Seleka fighters regroup in north". 5 February 2014. < http://www.hrw.org/news/2014/02/05/centralafrican-republic-seleka-fighters-regroup-north> Accessed on 29 October 2014.

${ }^{50}$ Herbert et al. op cit., p. 10.

${ }^{51}$ Rotberg op. cit., p. 87.

${ }^{52}$ Amnesty International. Central African Republic: Human Rights crisis spiralling out of control. London: Amnesty International Publications, 2013,

${ }^{53}$ Herbert et al. op cit., p. 8.

${ }^{54} \mathrm{~J}$ Giroux, D Lanz \& D Sguaitamatti. The tormented triangle: The regionalisation of conflict in Sudan, Chad and the Central African Republic. Crisis States working paper series no. 2, Peace working paper no. 47, Regional and Global Axes of Conflict. Crisis States Research Centre, Centre for Security Studies, ETH, and SwissPeace, April 2009, 2.

55 Amnesty International op. cit.

${ }^{56}$ Rotberg op. cit., 94.

${ }^{57}$ Mehler op. cit., p. 57.

58 Parliamentary Monitoring Group op. cit.

${ }^{59}$ See, for example F Parker. "Soldier deaths in the CAR the result of flawed foreign policy”. Mail \& Guardian. 26 March 2013. <http://mg.co.za/article/201303-26-soldier-deaths-in-car-the-result-of-flawed-foreign-policy $>$ Accessed 
on 26 August 2013; N Bauer. "CAR: Did Zuma defy the Constitution?” Mail and Guardian. 9 April 2013. <http://mg.co.za/article/2013-04-08-zumaconstitution-car-deployment-sandf $>$ Accessed on 26 April 2013; R Munusamy. "SA's role in the Battle of Bangui: The blood on Zuma's hands". The Daily Maverick. 27 March 2013.

<http://www.dailymaverick.co.za/article/2013-03-27-sas-role-in-the-battleof-bangui-the-blood-on-zumas-hands/\#.UhsxAxunqnk $>$ Accessed on 26 August 2013.

${ }^{60}$ defenceWeb. "SA attack helicopters in renewed action in the DRC". 3 March 2014.

<http://www.defenceweb.co.za/index.php?option=com_content\&view=articl e\&id=33815: sa-attack-helicopters-in-renewed-action-in-thedrc\&catid=35:Aerospace \&Itemid=107> Accessed on 1 December 2016; defenceWeb. "South African expertise and equipment again adds value to UN DRC operations". 12 March 2014.

<http://www.defenceweb.co.za/index.php?option=com content\&view=articl e\&id=33948: south-african-expertise-and-equipment-again-adds-value-to-undrc-operations\&catid=56:diplomacy-a-peace \&Itemid=111> Accessed on 1 December 2016; defenceWeb. "SANDF continental deployments extended". 26 March 2014.

<http://www.defenceweb.co.za/index.php?option=com_content\&view=articl e\&id=34142: sandf-continental-deployments-extended\&catid=111:sadefence \&Itemid=242> Accessed on 22 October 2014.

${ }^{61}$ L Engelbrecht. "Feature: National security strategy necessary - analysts". defenceWeb. 20 January 2011.

$<$ http://www.defenceweb.co.za/index.php?option=com_content\&view=articl e\&id=13124:feature-national-security-strategy-necessary--analysts\&catid=49:National+Security\&Itemid=115> Accessed on 27 August 2013.

62 J Stupart. "The three things the CAR taught us". Mail \& Guardian. 28 March 2013. <http://mg.co.za/article/2013-03-28-the-three-things-that-car-taughtus/> Accessed on 27 August 2013.

${ }^{63}$ See the speech by the South African Minister of Defence and Military Veterans during the Budget Vote for Defence and Military Veterans, Budget Vote 22, National Assembly. 23 July 2014.

<http://www.dod.mil.za/ministry/speeches/Budget\%20Vote\%202014.pdf $>$ Accessed on 24 July 2014

${ }^{64} \mathrm{G}$ Ashton. "South Africa's military adventurism: A dangerous shift in foreign policy”. The South African Civil Society Information Service. 3 April 2013. <http://www.sacsis.org.za/s/story.php?s=1622> Accessed on 27 July 2014. 
65 Ibid.

${ }^{66}$ Amabhungane Reporters. "Central African Republic: Is this what our soldiers died for?” Mail \& Guardian. 28 March 2014. <http://mg.co.za/article/2013-0328-00-central-african-republic-is-this-what-our-soldiers-died-for> Accessed on 22 October 2014; H Lustig. "What was the South African Military doing in the Central African Republic?" Vice. 25 April 2013. <http://www.vice.com/read/what-were-the-south-african-military-up-to-incentral-african-republic > Accessed on 23 October 2014.

${ }^{67}$ See the recent revelation by Mr Zwelinzima Vavi on the link between the visit by President Zuma to Equatorial Guinea and the business ventures of the Gupta-Zuma families in the CAR: S Hofstatter. "Alliance date with Zuma turns into Gupta-Duduzane show, Vavi recounts". Sunday Times. 27 March 2016.

<http://www.timeslive.co.za/sundaytimes/stnews/investigations/2016/03/27/ Alliance-date-with-Zuma-turns-into-Gupta-Duduzane-show-Vavi-recounts $>$ Accessed on 7 April 2016.

${ }^{68}$ Agency Staff. "ANC denies business links to Central African Republic". Business Day Live. 28 March 2013.

<http://www.bdlive.co.za/national/2013/03/28/anc-denies-business-links-tocentral-african-republic $>$ Accessed on 22 October 2014.

${ }^{69} \mathrm{C}$ Saunders. "Military intervention in conflict situations in Africa: Thoughts on South Africa's role”. Strategic Review for Southern Africa 35. 2. 2013.154.

${ }^{70}$ Parliamentary Monitoring Group op. cit.

71 Ibid.

72 D Maynier. "How the President misled Parliament on CAR". Business Day Live. 4 April 2013. <http://www.bdlive.co.za/opinion/2013/04/04/how-thepresident-misled-parliament-on-car $>$ Accessed on 27 July 2014.

${ }^{73}$ Maynier op. cit.

74 P Fabricius. "South Africa puts stamp on continent". The Sunday Independent. 2 February 2014.

75 South African Government. "South African Defence Review 2014”. 25 March 2014. 2-26. <http://www.gov.za/documents/south-african-defence-review2014> Accessed on 6 April 2016.

${ }^{76}$ Schoeman op. cit., p. 212.

77 Command, Control, Communications and Intelligence.

${ }^{78}$ Budget Vote 22 op. cit.

${ }^{79}$ Ibid.

${ }^{80}$ A McGregor. "The South African National Defence Force - A military in freefall. TerrorismMonitor XI. 1. 10 January 2013. 3, 5. 
〈http://www.jamestown.org/uploads/media/TM_011_Issue02_04.pdf $>$

Accessed on 7 April 2016.

${ }^{81}$ Budget Vote 22 op. cit.

${ }^{82}$ Parliamentary Monitoring Group. "SANDF decline, transformation, integration, equity and morale: Department of Defence overview”. 13 November 2014. <http://www.pmg.org.za/node/48309?utm_source=Drupal\&utm_medium=e mail\&utm_campaign=Free\%20Alerts $>$ Accessed on 18 November 2014.

83 AJ Esterhuyse. "The leadership factor in South African military culture". Defence Studies 13. 2. 135-151.

${ }^{84}$ E-mail discussion with a senior officer in the Joint Operations Division of the SANDF, 10 June 2014.

85 S Hofstatter \& J Oatway. "Blunders cost soldiers' lives in 'SA's Mogadishu"”. Sunday Times. 9 November 2014. 1.

<http://thetimes.newspaperdirect.com/epaper/viewer.aspx $>$ Accessed on 10 November 2014.

${ }^{86}$ See S Hofstatter. "It was controlled utter $\mathrm{f}^{* * * * * *}$ chaos". Sunday Times. 9

November 2014. 12.

<http://www.timeslive.co.za/sundaytimes/2014/11/09/it-was-controlledutter-f-chaos> Accessed on 10 November 2014; also see S Hofstatter. "A desperate prayer in the shadow of death". Sunday Times. 9 November 2014.

12. <http://www.timeslive.co.za/sundaytimes/2014/11/09/a-desperateprayer-in-the-shadow-of-death $>$ Accessed on 10 November 2014.

${ }^{87}$ E-mail correspondence with a member from DIRCO, 13 June 2014; also see S Hofstatter \& P Joubert. “Zuma's secret deal with dictator”. Times Live. 25 August 2013. <http://www.timeslive.co.za/politics/2013/08/25/zuma-ssecret-deal-with-dictator1> Accessed on 22 October 2014.

88 Parliamentary Monitoring Group. "Defence Minister ... op. cit.

${ }^{89}$ Brief by the SANDF Force Commander in the CAR at the South African Military Academy, 14 October 2013. 